\title{
Efficacy and Safety of Convalescent Plasma Transfusion Administered as Adjunctive Treatment to Standard Treatment in Moderate, Severe, and/or Critically III Patients with COVID-19 in Dr. M. Djamil General Hospital
}

\author{
Irza Wahid ${ }^{1 *}{ }^{1 *}$, E. Faheri ${ }^{1}$, E. P. Andani ${ }^{2}$, Fauzar Fauzar ${ }^{3}$, D. R. Zelly ${ }^{4}$, Widyarman Widyarman ${ }^{5}$, I. Medison $^{6}$, E. Taslim $^{7}$, \\ T. Handayani ${ }^{8}$ \\ ${ }^{1}$ Department of Internal Medicine, Subdivision of Hematology-Oncology, Medical Faculty, Andalas University, Dr. M. Djamil \\ Hospital, Padang, Indonesia; ${ }^{2}$ Department of Microbiology, Central Laboratory of Diagnostic and Research of Infectious Diseases, \\ Andalas University, Padang, Indonesia; ${ }^{3}$ Department of Internal Medicine, Subdivision of Pulmonology, Medical Faculty, Andalas \\ University, Dr. M. Djamil Hospital, Padang, Indonesia; ${ }^{4}$ Department of Clinical Pathology, Medical Faculty, Andalas University, Dr. \\ M. Djamil Hospital, Padang, Indonesia; ${ }^{5}$ Head of Blood Bank, Indonesian Red Cross Society, Padang, Indonesia; ${ }^{6}$ Department of \\ Pulmonology, Medical Faculty, Andalas University, Dr. M. Djamil Hospital, Padang, Indonesia; ${ }^{7}$ Department of Anaesthesiology \\ and Intensive Therapy, Medical Faculty, Andalas University, Dr. M. Djamil Hospital, Padang, Indonesia; ${ }^{8}$ Department of Radiology, \\ Medical Faculty, Andalas University, Dr. M. Djamil Hospital, Padang, Indonesia
}

Edited by: Ksenija Bogoeva-Kostovska Citation: Wahid 1, Far T. Efficacy and Safety of Convalescent Plasm Transfusion Administered as Adjunctive Treatment to dard Treatment in Moderate, Severe, and/or Critically III Patients with COVID-19 in Dr. M. Djamil Genera Hospital. Open-Access Maced J Med Sci. 2021 Nov 17 (B):1489-1493.https://doi.org/10.3889/oamjms.2021.677 Keywords: Coronavirus disease 2019; Convalescent plasma therapy; C-reactive protein Correspondence: IIza Wahid, Department of Internal Faculty of Andalas University, Dr. M. Djamil Hospital, mil Hospita Padang, Indonesia
E-mail: irzawahid_drsppd@yahoo.co.id
Received: 16-Aug-2021 Revised: 13 -Sep-202 Accepted: 12-Nov-2021
Copyright: $\odot 2021$ Irza Wahid, E. Faheri, E. P. Andani, Fauzar Fauzar, D. R. Zelly, Widyarman Widyarman, Funding: This research did not receive any financial

Funding: This research did not receive any financia competing interest exists access article distributed Open Access: This is an open-access article distribute
under the terms of the Creative Commons AttributionNonCommercial 4.0 International License (CC BY-NC 4.0)

\begin{abstract}
BACKGROUND: Coronavirus disease 2019 (COVID-19) is a respiratory disease caused by severe acute respiratory syndrome coronavirus 2 . High mortality rate due to COVID-19 has become a serious health problem globally. A
\end{abstract} present, there is no definitive therapy for COVID-19.

AIM: The objective of this study is to evaluate convalescent plasma therapy (CPT) in COVID-19 patients

METHODS: The study was conducted in prospective experimental design with sample population of COVID-19 inpatient in Dr. M. Djamil General Hospital, Padang, isolation ward. This study was involving 20 patients consisted of 10 patients of experimental group who received standard therapy and CPT and 10 patients of control group who received standard therapy only; 10 males and 10 females. Differences in laboratory results in both groups were analyzed by T-test or Mann-Whitney U-test.

RESULTS: Twenty subjects included in this study with average of age 56.50 (9.606) years. The mean of C-reactive protein (CRP) serum of the experimental group on day $1(\mathrm{CRP}+1)$ after CPT was $17.50(25.343)$ while the contro group was $77.50(75.177)$ with $p=0.028(p<0.05)$. However, there were no differences in sequential organ failure assessment, hemoglobin, leukocyte, platelet, partial pressure of oxygen, D-dimer, procalcitonin, interleukin-6, lactate dehydrogenase, ferritin, aspartate aminotransferase, alanine aminotransferase, urea, creatinine, glomerular filtration rate, bilirubin, cycle threshold values, and chest X-ray finding between both groups

CONCLUSION: There was a significant difference in CRP +1 between the experimental group and control group while no significant differences found in other parameters between both groups. As CRP is an inflammatory indicator CPT showed benefit in reducing inflammation in COVID-19 patient.

\section{Introduction}

Coronavirus disease 2019 (COVID-19) is a respiratory disease caused by severe acute respiratory syndrome coronavirus 2 (SARS-CoV-2) and was first reported in Wuhan city, Hubei Province, China. As 2021, the World Health Organization has been informed of more than 167 million cases of COVID-19, with 3.47 million deaths documented worldwide [1], [2], [3].

As of May 2021, there have been 1.6 million positive COVID-19 cases in Indonesia, reaching 46,496 deaths, placing Indonesia as country with highest mortality rate in Southeast Asia. In West Sumatera, number of positive cases of COVID-19 reached 38,261 with $2.18 \%$ mortality rate and 834 deaths. High mortality rate due to COVID-19 has become a serious health problem in Indonesia, even in the world. However, currently, there is no definitive therapy for COVID-19 [4].

Convalescent plasma therapy involves the administration of antibodies against a given agent to a susceptible individual for the purpose of preventing or treating an infectious disease due to that agent. In contrast, active vaccination requires the induction of immune response that takes time to develop, thus convalescent plasma therapy (CPT) providing immediate immunity to susceptible persons. CPT has a storied history going back to the 1940s of treating certain infectious diseases before antimicrobial therapy. In the early $20^{\text {th }}$ century, convalescent plasma 
$(\mathrm{CP})$ is used to stem outbreaks of viral diseases such as poliomyelitis, measles, mumps, and influenza. CPT has been shown to be effective in several cases of viral infections, including SARS-CoV, H5N1 avian influenza, Ebola, Middle-East Respiratory Syndrome, and H1N1 influenza [5], [6], [7], [8], [9], [10].

A study in China documented 10 patients with severe COVID-19 showed clinical improvement, decreasing viral load to negative seroconversion on the $2^{\text {nd }}$ and $3^{\text {rd }}$ day after transfusion. This study also showed a good clinical outcome; three cases discharged while seven cases in much improved status [11]. Therefore, with the development of CPT and promising result from its study, this research was carried out to improve quality of life of COVID-19 patients in Indonesia, especially in the West Sumatera region.

\section{Methods}

This study conducted with a clinical trial design in the isolation ward of Dr. M Djamil Hospital, Padang, held in August 2020-January 2021. The diagnosis of COVID-19 was confirmed by polymerase chain reaction $(\mathrm{PCR})$ swab. Subjects were divided into two groups, the recipient group with standard therapy and CPT administration and the control group with standard therapy only. The population of this study is hospitalized patients with COVID-19 in isolation ward of $\mathrm{Dr}$. M. Djamil Hospital. The samples are the patients who met inclusion criteria such as age over 18 years, positive PCR test results of COVID-19 from naso-oropharyngeal swab, and patients with moderate, severe, or critical degree of disease. Recipient exclusion criteria were patients with incomplete clinical data, allergic history to plasma or other blood components, critical degree COVID-19 with sequential organ failure assessment (SOFA) score $>11$ and $53 \%$ mortality risk, and if the patients or family did not agree to participate in the study. Meanwhile, voluntary CP donors were recruited based on the following criteria: Aged 18-60 years, have recovered from COVID-19 confirmed with two consecutive negative reverse transcription PCR tests, preferably men or women who have never been pregnant; symptom-free for more than 14 days before plasma donation, do not have other comorbidities such as diabetes mellitus on insulin; severe hypertension; chronic kidney disease; difficult vascular access; and seronegativity from transmitted infections through blood transfusions. The anti-SARS-CoV-2-specific IgG serum antibody titer of the donors should be more than 1:320. Exclusion criteria for $\mathrm{CP}$ donors were incomplete clinical information during COVID-19 treatment or incompatible cross-match test results, hemoglobin $(\mathrm{Hb})$ level $<12.5 \mathrm{~g} /$ $\mathrm{dL}$, pregnant, hypotension, history of cancer, history of liver disease, history of narcotics use by injection, and if candidate did not agree to participate.
The parameter data were compared between those groups. The parameter data consisted of $\mathrm{Hb}$, leukocyte, thrombocyte, partial pressure of oxygen (PO2), D-Dimer, procalcitonin (PCT), interleukin (IL)6 , lactate dehydrogenase (LDH), ferritin, aspartate aminotransferase (AST), alanine aminotransferase $(A L T)$, urea, creatinine, glomerular filtration rate (GFR), bilirubin, cycle threshold (CT) value, and chest X-ray findings. The laboratorium parameters were examined at M. Djamil general hospital laboratorium by clinical pathologist while the chest $\mathrm{X}$-ray finding was interpreted by radiologist.

Data were processed and analyzed using SPSS 26. Different variables between the two groups were analyzed by Chi-square test and differences in laboratory findings were analyzed by t-test if the data distribution was normal. Mann-Whitney U-test was used when the data not normally distributed. $p<0.05$ is declared as statistically significant. This study was approved by Health Research Ethics Committee, Dr. M Djamil Hospital, Padang (No.396/KEPK/2020).

\section{Results}

During the study period, 20 patients met the criteria. There were basic characteristics of research subject, as shown in Table 1.

Table 1: Subject characteristics data

\begin{tabular}{|c|c|c|c|c|c|}
\hline \multicolumn{3}{|l|}{ Recipient $(n=10)$} & \multicolumn{2}{|c|}{ Control $(n=10)$} & \multirow[t]{2}{*}{$p$} \\
\hline Characteristic & $\mathrm{n}(\%)$ & Mean $\pm S D$ & $\overline{\mathrm{n}(\%)}$ & Mean \pm SD & \\
\hline Age (years) & & $56.50 \pm 9.606$ & & $58.50 \pm 10.937$ & 0.684 \\
\hline Gender & & & & & 0.371 \\
\hline Men & $6(60)$ & & $4(40)$ & & \\
\hline Women & $4(40)$ & & $6(60)$ & & \\
\hline Degree & & & & & 0.476 \\
\hline Severe & $8(80)$ & & $8(80)$ & & \\
\hline Critical & $2(20)$ & & $2(20)$ & & \\
\hline SOFA score & & $2.20 \pm 3.293$ & & $3.60 \pm 4.248$ & 0.269 \\
\hline $\mathrm{Hb}(\mathrm{g} / \mathrm{dl})$ & & $12.0400 \pm 1.18809$ & & $12.5500 \pm 2.21723$ & 0.117 \\
\hline Leukocyte $\left(/ \mathrm{mm}^{3}\right)$ & & $14238.90 \pm 6441.837$ & & $15877.00 \pm 9445.016$ & 0.261 \\
\hline Platelet $\left(/ \mathrm{mm}^{3}\right)$ & & $213500.0 \pm 60231.498$ & & $230000.0 \pm 90580.842$ & 0.310 \\
\hline $\mathrm{PO}_{2}(\mathrm{mmHg})$ & & $83.4000 \pm 34.32938$ & & $76.8100 \pm 42.61928$ & 0.994 \\
\hline D-dimer (ng/ml) & & $5142.70 \pm 4054.066$ & & $4680.50 \pm 3782.884$ & 0.698 \\
\hline $\mathrm{CRP}(\mathrm{mg} / \mathrm{l})$ & & $56.80 \pm 52.002$ & & $79.00 \pm 61.023$ & 0.491 \\
\hline PCT $(\mathrm{mg} / \mathrm{ml})$ & & $21.9180 \pm 62.79930$ & & $10.6260 \pm 31.30824$ & 0.330 \\
\hline IL6 (pg/ml) & & $22.4380 \pm 19.07589$ & & $939.4700 \pm 2472.2842$ & 0.040 \\
\hline $\operatorname{LDH}(\mathrm{u} / \mathrm{l})$ & & $723.59 \pm 304.696$ & & $711.40 \pm 171.847$ & 0.186 \\
\hline Feritin (ng/ml) & & $1012.235 \pm 463.16365$ & & $948.4740 \pm 365.22286$ & 0.777 \\
\hline AST $(\mathrm{u} / \mathrm{l})$ & & $41.60 \pm 26.031$ & & $514.80 \pm 1305.420$ & 0.041 \\
\hline $\operatorname{ALT}(\mathrm{u} / \mathrm{l})$ & & $48.80 \pm 39.276$ & & $504.60 \pm 1274.750$ & 0.045 \\
\hline Ureum (mg/dl) & & $57.70 \pm 38.517$ & & $90.50 \pm 98.775$ & 0.009 \\
\hline Creatinine (mg/dl) & & $1.3900 \pm 1.92611$ & & $5.9700 \pm 11.06778$ & 0.036 \\
\hline CKDEPI & & $86.6200 \pm 36.51751$ & & $65.8400 \pm 39.49906$ & 0.474 \\
\hline Bilirubin 1 (mg/dl) & & $0.3720 \pm 0.21872$ & & $0.4800 \pm 45656$ & 0.077 \\
\hline Bilirubin $2(\mathrm{mg} / \mathrm{dl})$ & & $0.5000 \pm 0.58500$ & & $0.8100 \pm 0.83858$ & 0.098 \\
\hline CT Value & & $28.7130 \pm 5.17977$ & & $27.8550 \pm 3.61712$ & 0.266 \\
\hline Chest X-ray & & $0.475 \pm 0.24$ & & $0.40 \pm 0.17$ & 0.453 \\
\hline
\end{tabular}

Ten recipients and 10 controls enrolled in this study. In the experimental group, 6 were men (60\%) and 4 are women $(40 \%)$, with average age of 56.50 (9.606) years, meanwhile in the control group, there were 4 men $(40 \%)$ and 6 women $(60 \%)$, with an average age 
58.50 (10.937) years. Eight cases $(80 \%)$ were classified as severe while 2 cases $(20 \%)$ were critical cases in the recipient group. The control group consisted of 7 cases $(70 \%)$ severe cases and 3 cases $(30 \%)$ as critical cases. Based on laboratory parameter data, as shown in Figure 1, there was no difference in SOFA, $\mathrm{Hb}$, leukocyte, thrombocyte, PO2, D-Dimer, PCT, IL-6, LDH, ferritin, AST, ALT, ureum, creatinine, GFR, bilirubin, CT value, and chest $\mathrm{X}$-ray findings of the control group compared to the experimental group $(p>0.05)$ after administration of CP.

However, there was a significant difference of C-reactive protein (CRP) value on the $1^{\text {st }}$ day after CP transfusion (CRP +1 ) between the experimental and control groups $(p<0.05)$. In the experimental group, mean value of CRP +1 was 17.50 (25.343), while in the control group was 77.50 (75.177).

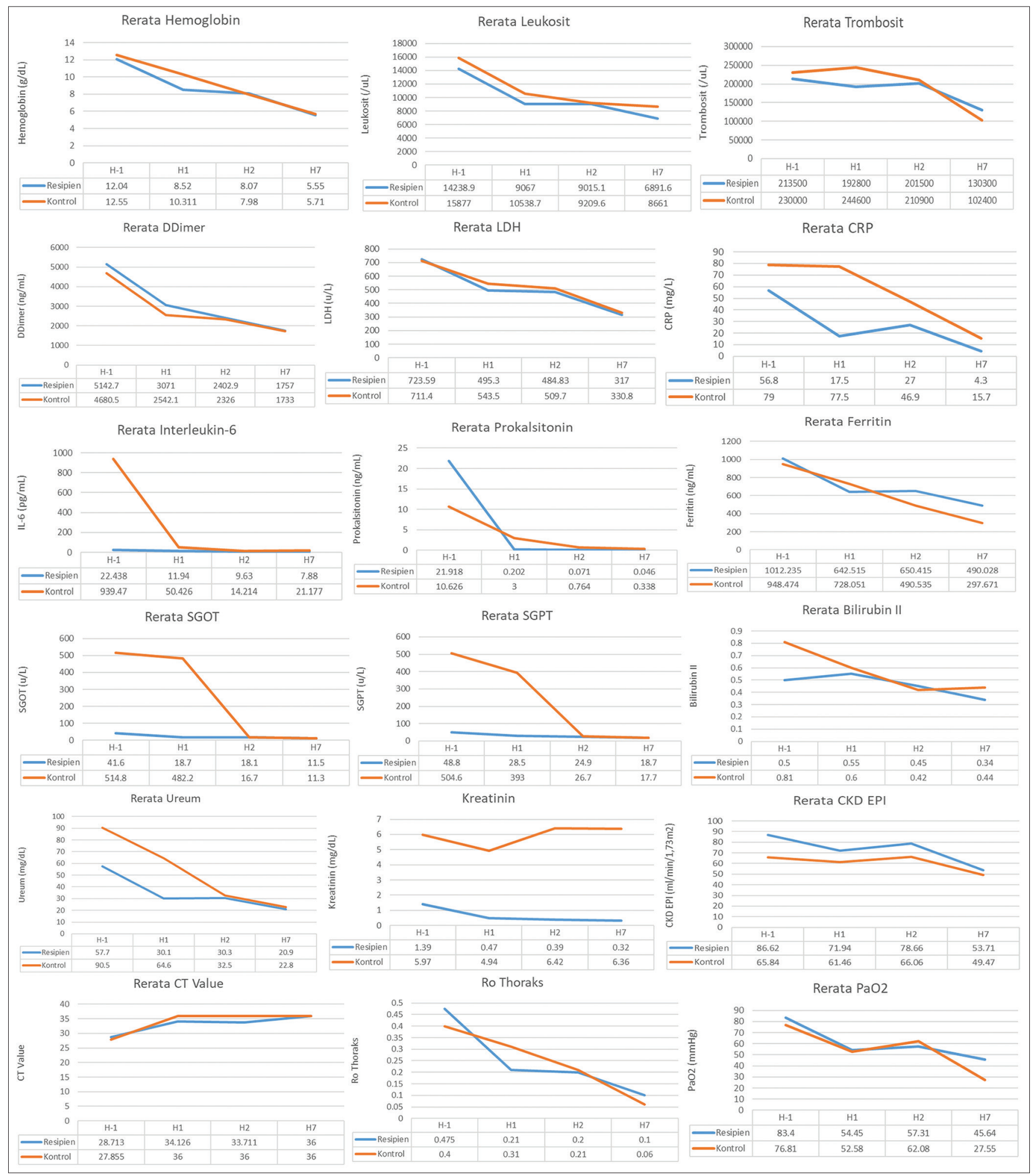

Figure 1: The experimental and control groups laboratory data during pre-transfusion (D-1), post-transfusion $D+1, D+2$, and $D+7$ 


\section{Discussion}

This study compared the parameters between the recipient and control groups. The parameters examined were $\mathrm{Hb}$, leukocyte, thrombocyte, $\mathrm{PO}$, D-Dimer, PCT, IL-6, LDH, ferritin, AST, ALT, ureum, creatinine, GFR, bilirubin, CT value, and chest X-ray findings.

Mean CRP +1 value in the recipient group was $17.50(25.343) \mathrm{mg} / \mathrm{L}$, while in the control group was $77.50(75.177) \mathrm{mg} / \mathrm{L}$. According to Xia et al., CRP levels increased significantly in patients who did not respond to CP (non-responders) with consecutive results: $5.2 \mathrm{mg} / \mathrm{L}$ in responders, $25.9 \mathrm{mg} / \mathrm{L}$ in partial responders, and $73.1 \mathrm{mg} / \mathrm{L}$ in non-responders. It clearly showed that strong inflammatory reaction is associated with $\mathrm{CP}$ insensitive response. According to $\mathrm{Hu}$ et al., inflammatory indicators (CRP) significantly decreased (median $44 \mathrm{mg} / \mathrm{L}$ vs. $18 \mathrm{mg} / \mathrm{L}$ ) after CP administration. COVID-19 is associated with severe inflammatory reaction, as in this study showed significant CRP reduction after $\mathrm{CP}$ administration. It could be stated that $\mathrm{CP}$ can reduce cytokine storms. Based on research conducted by Li et al., administration of CPT as standard therapy did not provide significant clinical improvement in 28 days. This study was conducted on 103 severe and critical cases of COVID-19 [12], [13], [14].

Simonovich et al. were also reported things that are consistent with the previous study. From 228 severe COVID cases, they found that there was no significant difference in clinical status or mortality rate between the experimental group and control. Another study by Agarwal et al. also shows similar results. This study was conducted on 235 moderate COVID-19, with $\mathrm{PaO} 2 / \mathrm{FiO} 2$ criteria were $200-300 \mathrm{mmHg}$ or respiratory rate more than $24 \mathrm{times} / \mathrm{min}$ in $<93 \%$ oxygen saturation room air. The study stated that 28-day mortality in the CP group was $19 \%$ while in the control group was $18 \%$. Therefore, this study concluded that CPT was not associated with declining progressivity or mortality rate. This study also reported that there was no difference in the inflammatory markers such as ferritin, CRP, D-Dimer, or LDH between the two groups. Actually, evidence of CPT as an immunomodulator cannot be suggested. According to RECOVERY 2021 study, there was no significant difference in the 28-day mortality rate between the CP group and the control group, with $24 \%$ mortality rate in both of groups. This study noted that CP did not improve survival rates or clinical outcome in hospitalized COVID-19 cases. A study by Agarwal et al. conducted on 40 cases COVID-19 with radiological evidence of pneumonia whom acquiring oxygen therapy also reported similar results. Primary outcomes stated in this study were need for mechanical ventilation, meanwhile, secondary outcomes were leukocytes, LDH, CRP, troponin, ferritin, D-Dimer, PCT, and 28-day mortality. There was no significant difference in both primary and secondary outcomes between the $\mathrm{CP}$ group and control group [15], [16]. The limitation of this study is the low number of samples.

\section{Conclusion}

There was a significant difference in CRP +1 value between the control and experimental groups, but there were no significant differences in SOFA scores, $\mathrm{Hb}$, leukocyte, platelet, PO2, D- dimer, PCT, IL-6, LDH, ferritin, AST, ALT, urea, creatinine, LFG, bilirubin, CT value, and chest $\mathrm{X}$-ray findings between the control and experimental groups. As CRP is an inflammatory indicator, CPT showed benefit in reducing inflammation in COVID-19 patient.

\section{References}

1. Guan W, Ni Z, Hu Y, Liang W, Ou C, He J, et al. Clinical characteristics of coronavirus disease 2019 in China. N Engl J Med. 2020;382:1708-20. https://doi.org/10.1056/ nejmoa2002032

2. Jin $Y$, Yang H, Ji W, Wu W, Chen S, Zhang W, et al. Virology, epidemiology, pathogenesis, and control of COVID-19. Viruses. 2020;12(4):372. https://doi.org/10.3390/v12040372 PMid:32230900

3. World Health Organization. Coronavirus Disease 2019 (COVID19) Situation Report-77. Geneva: World Health Organization; 2020 b.

4. Kementerian Kesehatan Republik Indonesia. Pedoman Pencegahan dan Pengendalian Coronavirus Disease (COVID-19). $4^{\text {th }}$ ed. Jakarta: Kementerian Kesehatan Republik Indonesia; 2020.

5. Casadevall A, Pirofski L. The convalescent sera option for containing COVID-19. J Clin Invest. 2020;130(4):1545-8. https:// doi.org/10.1172/jci138003 PMid:32167489

6. Zhou B, Zhong N, Guan Y. Treatment with convalescent plasma for influenza a (H5N1) infection. $N$ Engl J Med. 2007;357(14):1450-1. https://doi.org/10.1056/nejmc070359 PMid:17914053

7. Hung IF, To KK, Lee CK, Lee KL, Chan K, Yan WW, et al Convalescent plasma treatment reduced mortality in patients with severe pandemic influenza a (H1N1) 2009 virus infection. Clin Infect Dis. 2011;52(4):447-45. https://doi.org/10.1093/cid/ ciq106

PMid:21248066

8. Florescu DF, Kalil AC, Hewlett AL, Schuh AJ, Stroher U, Uyeki TM, et al. Administration of brincidofovir and convalescent plasma in a patient with Ebola virus disease. Clin Infect Dis. 2015;61(6):969-73. https://doi.org/10.1093/cid/civ395 PMid:25991468

9. Kraft CS, Hewlett AL, Koepsell S, Winkler AM, Kratochvil CJ, Larson L, et al. The use of TKM-100802 and convalescent plasma in 2 patients with Ebola virus disease in the United States. Clin Infect Dis. 2015;61(4):496-502. https://doi. 
org/10.1093/cid/civ334.12

PMid:25904375

10. Van Griensven J, Edwards T, de Lamballerie X, Semple MG, Gallian P, Baize S, et al. Evaluation of convalescent plasma for Ebola virus disease in guinea. N Engl J Med. 2016;374:33-42. https://doi.org/10.1056/nejmoa1511812

11. Duan K, Liu B, Li C, Zhang H, Yu T, Qu J, et al. Effectiveness of convalescent plasma therapy in severe COVID-19 patients. Proc Natl Acad Sci. 2020;117(17):9490-6. https://doi.org/10.1073/ pnas. 2004168117

PMid:32253318

12. Xia X, Li K, Wu X, Wang Z, Zhu M, Huang B, et al. Improved clinical symptoms and mortality among patients with severe or critical COVID-19 after convalescent plasma transfusion. Blood. 2020;136(6):755-9. https://doi.org/10.1182/ blood.2020007079

PMid:32573724

13. Hu X, Hu C, Jiang D, Zuo Q, Li Y, Wang Y, et al. Effectiveness of convalescent plasma therapy for COVID-19 patients in
Hunan, China. Dose Response. 2020;18(4):1-12. https://doi. org/10.1177/1559325820979921

PMid:33402882

14. Li L, Zhang W, Hu Y, Tong X, Zheng S, Yang J, et al. Effect of convalescent plasma therapy on time to clinical improvement in patients with severe and life-threatening COVID-19: A randomized clinical trial. JAMA. 2020;324(5):460-70. https:// doi.org/10.1001/jama.2020.10044

PMid:32492084

15. Simonovich VA, Pratx B, Scibona P, Beruto MV, Vallone MG, Vazquez $\mathrm{C}$, et al. A randomized trial of convalescent plasma in COVID-19 severe pneumonia. N Engl J Med. 2020;384:619-29. https://doi.org/10.1056/NEJMoa2031304

16. Agarwal A, Mukherjee A, Kumar G, Chatterjee P, Bhatnagar $T$, Malhotra $\mathrm{P}$, et al. Convalescent plasma in the management of moderate COVID-19 in adults in India: open label phase II multicenter randomized controlled trial (PLACID Trial). BMJ. 2020;371:m3939. https://doi.org/10.1136/bmj.m3939

PMid:33093056 